\title{
O Rito da Missa enquanto Prática Sacramental Católica
}

\author{
The Rite of Mass as Catholic Sacramental Practice
}

\section{Sueli Maria Ramos da SILVA*}

Resumo: Este trabalho se ampara no desenvolvimento da noção semiótica de estilo com a operacionalização da noção de éthos proposta por Discini (2004). Procuramos agregar a noção de estilo enquanto éthos, tom de voz, caráter e corporalidade depreensível de uma totalidade de discursos (DISCINI, 2004), ao ponto de vista tensivo proposto por Zilberberg (2006) em referência às noções de estilo ascendente e descendente estabelecidas pelo autor. Pretendemos, dessa forma, delinear de forma mais abrangente o modo de presença dos enunciados enfeixados pelo discurso de fidelização religiosa. Nosso trabalho espera contribuir com o exame da própria esfera de circulação do sentido religioso, ou seja, com reflexões a respeito do discurso religioso, como enunciado, enunciação, éthos, estilo e aspecto.

Palavras-chave: Semiótica tensiva. Retórica. Discurso de fidelização religiosa.

Abstract: Our work is supported by the development of the Semiotic sense of style with the operationalization of the notion of ethos proposed by Discini (2004). In this direction, we seek to add the notion of ethos as style, tone, voice, character and corporeality which can be understood as a totality of discourses (DISCINI, 2004), to the tensive point of view proposed by Zilberberg (2006) in reference to the notions of upward and downward motions style set forth by the author. We propose, therefore, to delineate more fully the manner of presence of the enunciation set out to discourse of religious loyalty. Our work tries to contribute to the examining one's

\footnotetext{
* Doutora em Semiótica e Linguística Geral - FFLCH-USP (2012). Mestre em Linguística pelo Programa de Pós-Graduação em Semiótica e Linguística Geral da FFLCH-USP (2007). Professora Doutora da área de Linguística do Programa de Mestrado em Letras em Linguagem, Cultura e Discurso da Universidade Vale do Rio Verde - Unincor Três Corações-MG. Contato: sueliling@yahoo.com.br.
} 
own sphere of circulation of the religious sense, that is, with reflections on the religious discourse, as stated, enunciation, ethos, style and appearance. Key-words: Tensive semiotic. Rhetoric. Discourse of religious loyalty.

\section{Introdução}

Procuramos examinar os mecanismos de produção do efeito de sentido afetivo ou passional depreensível do rito da missa enquanto prática ritualística sacramental católica.

Dentre os enunciados pertencentes à prática de fidelização própria ao domínio religioso católico, estabelecemos como recorte analítico o folheto litúrgico (suporte do rito eucarístico), também denominado semanário litúrgico catequético. Trata-se, aqui, mais do que o exame do enunciado em si, de sua compreensão enquanto processo, interação e prática social (LANDOWSKI, 2004, p. 16). Temos, ainda, como objeto de estudo a noção de práticas semióticas empreendida por Fontanille (2008), bem como os desenvolvimentos de Blanco (2008). Ampliaremos as proposições de Blanco, que procurou tratar o rito da missa enquanto uma prática ritual. Para isso, realizamos a inclusão do folheto litúrgico, objeto-suporte do rito eucarístico ${ }^{1}$.

Dentre os folhetos litúrgicos em circulação no domínio religioso católico, estabelecemos como recorte o folheto O Povo de Deus em São Paulo, publicação da Mitra Arquidiocesana de São Paulo. A Arquidiocese de São Paulo constitui uma circunscrição da Igreja Católica no Brasil, Sé Metropolitana da Província Eclesiástica de São Paulo, pertence ao Conselho Episcopal Regional Sul I da Conferência Nacional dos Bispos do Brasil (CNBB).

O folheto litúrgico, ao compor-se como um enunciado de fidelização religiosa, configura um gênero textual pertencente à esfera de circulação do discurso religioso e apresenta como elemento constitutivo de sua temática a reatualização do sacrifício eucarístico. O folheto litúrgico caracteriza-se, portanto,

${ }^{1}$ O nível do objeto-suporte, em seu movimento de integração às práticas, é um caso exemplar do tratamento das propriedades materiais. Enquanto corpo material, na verdade, o objeto entra nas práticas e os usos dessas práticas são em si mesmos "enunciações" do objeto. Sob esse aspecto, o objeto em si só pode conter traços desses usos [...], ou seja, "vestígios enunciativos" (FONTANILLE, 2008, p. 25). 
mediante a sua utilização como subsídio para a participação dos fiéis à Santa Missa. Esse folheto tem ainda a propriedade de promover a unidade dos católicos nas celebrações dominicais da Arquidiocese e de outras paróquias que o assinam. O Povo de Deus em São Paulo assinala-se como um canal de comunicação dos principais eventos da Igreja de São Paulo. Contemporaneamente, o folheto O Povo de Deus em São Paulo apresenta sua difusão por meio de assinaturas realizadas pelas paróquias, totalizando cerca de 70 mil exemplares por domingo. Levando em conta que o suporte também é determinante para a depreensão do sentido do texto, reproduzimos o enunciado do folheto na sessão anexos deste artigo.Ao pertencer à esfera de atividades institucionalizadas da prática religiosa católica, o folheto litúrgico configura-se como um instrumento autorizado a ser usado como subsídio às ações litúrgicas da Santa Missa.

\section{Folheto Litúrgico - Semanário Litúrgico-Catequético: análise semiótica}

Contemplemos, inicialmente, a composição diagramática do enunciado do folheto (cf. Anexos). Ao observar o enunciado, verificamos que ele se constitui por uma composição diagramática pautada pelo efeito de sentido de simplicidade, em correspondência aos ideais didáticos de brevidade e clareza propostos pelo plano do conteúdo (PC). A própria materialidade do enunciado, determinado pelo tipo de papel (papel de jornal ${ }^{2}$ ), é característica da publicação ${ }^{3}$ e de sua difusão como objeto-suporte do rito eucarístico.

A noção de "modo de difusão" se emparelha à de "modo de consumo” (MAINGUENEAU, 2005, p. 141), que corresponde ao modo como esse discurso é lido, consumido e manipulado.

2 "Papel de qualidade um pouco inferior à dos demais papéis de impressão, com superfície áspera e pouco encolado, geralmente usado na impressão de jornais, devido a seu baixo custo, rápida secagem e outras conveniências de produção" (RABAÇA; BARBOSA, 1987, p. 444).

${ }^{3}$ Caracteriza-se o folheto como uma "publicação não-periódica, com número limitado de páginas (mínimo de 5, máximo de 48, excluídas as capas" (RABAÇA; BARBOSA, 1987, p. 274). 
No plano de expressão (PE), notamos o título-síntese do enunciado disposto no alto, em letra de tamanho maior, em caixa alta e de cromatismo preto sob um fundo azul. Esse cromatismo perpassa toda a composição do folheto litúrgico, que é composto dessas mesmas cores "preto e azul", presentes na própria segmentação do enunciado em partes.

Tomamos, como base, o folheto O Povo de Deus em São Paulo, de 16 de maio de 2010.

No que concerne à coerção genérica, a sua forma composicional, portanto, ele apresenta a seguinte estrutura: a) divisão em cinco atos e algumas cenas intermediárias, em referência ao rito eucarístico; b) ancoragem espacial e temporal representada sob a forma de cabeçalho; c) presença de uma ilustração didática.

Examinemos, inicialmente, a disposição desse gênero em cinco grandes atos e algumas cenas intermediárias. Essa segmentação dada no plano textual se estabelece em correspondência ao rito eucarístico do qual o enunciado do folheto serve como objeto-suporte:
a) Ritosiniciais
1. ${ }^{4}$ Acolhida
2. Saudação
3. Ato Penitencial
4. Hino de Louvor
5. Oração

b) Liturgia da Palavra

6. Primeira Leitura (Antigo Testamento)

7. Salmo Responsorial

8. Segunda Leitura (Novo Testamento)

9. Aclamação ao Evangelho

10. Evangelho

(Homilia)

11. Profissão de fé

12. Oração dos fiéis

${ }^{4}$ A numeração que antecede cada uma das cenas intermediárias refere-se à numeração original, tal como cada uma dessas seções aparece no folheto em análise (cf. Anexos). 


\section{c) Liturgia Eucarística}

13. Apresentação das oferendas

14. Oração sobre as oferendas

15. Oração eucarística

d) Rito da Comunhão

16. Pai Nosso

17. Canto de comunhão

18. Oração após a comunhão

19. Oração ao nosso patrono (opcional)

e) Ritosfinais

20. Bênção e despedida

21. Canto Final

Comunicados da Arquidiocese

Leituras da Semana

A ancoragem espacial e temporal é representada no enunciado sob a forma de cabeçalho: "São Paulo, 16 de maio de 2010. Ano 34. Lt 4. No. 33. C".

A referência a São Paulo espacializa o enunciado enquanto uma publicação a ser utilizada pelas paróquias pertencentes à Arquidiocese de São Paulo. O ano "33" refere-se aos anos de edição do folheto.

As letras "A", "B" e "C" correspondem ao modo como foram distribuídos os evangelhos dominicais. Por meio delas, temos a representação da leitura do evangelho correspondente a um determinado ano. Verificamos as leituras do evangelho de Mateus (Ano A), Marcos (Ano B) e, no caso, Lucas (Ano C).

A cada ano, os cristãos revivem as etapas consideradas mais importantes da vida de nosso Senhor: nascimento, morte, ressurreição, ascensão e envio do Espírito Santo. Assim como no ano civil, somos orientados pelas estações do ano e festas cívicas, o Ano Litúrgico ${ }^{5}$ orienta os

${ }^{5} \mathrm{O}$ ano litúrgico é o desdobramento de diversos aspectos do único mistério pascal. Isto vale muito particularmente para o ciclo das festas em torno do mistério da encarnação (Anunciação, Natal, Epifania) que comemoram o começo de nossa salvação e nos comunicam as primícias do Mistério da Páscoa (JOÃO PAULO II, 2000, p. 330). 
fiéis em sua caminhada de fé, marcada pelos momentos fortes da vida do Senhor (BORTOLINI, 2006, p. 7).

O Ano Litúrgico apresenta-se organizado em etapas. O primeiro modo de compreender a sua organização é caracterizá-lo por meio de ciclos. "Ciclo é um período em que ocorrem fatos históricos importantes a partir de um acontecimento, seguindo uma determinada evolução" (BORTOLINI, 2006 , p. 8). O primeiro fato histórico considerado mais importante da vida de Cristo é o seu nascimento, o Natal. Temos, assim, o estabelecimento do primeiro ciclo, o Ciclo do Natal. Esse fato está ligado a outros, que o antecedem e o seguem e que compõem juntamente com o nascimento de Cristo o ciclo do Natal. São eles: Advento, Natal, Sagrada Família, festa da Mãe de Deus, Epifania e Batismo do Senhor.

A Páscoa caracteriza-se como o segundo fato histórico mais importante. Fazem parte do Ciclo da Páscoa: Quaresma, Semana Santa, Tríduo Pascal, Páscoa, domingos da Páscoa (Ascensão) e Pentecostes. O terceiro e mais longo período do ano, com 34 domingos, recebe a designação de Tempo Comum. O Ano Litúrgico se inicia no primeiro domingo do Advento e termina no $34^{\circ}$ domingo do Tempo Comum.

O tempo litúrgico em que o enunciado do folheto se situa é o Ciclo da Páscoa, em remissão à "Ascensão do Senhor", título do folheto.

Vejamos o que representa a Ascensão, dentro do domínio religioso católico:

A Ressurreição de Jesus é a verdade culminante da nossa fé em Cristo e representa, com a Cruz, uma parte essencial do Mistério Pascal. [...] Depois de quarenta dias, período em que se mostrou aos Apóstolos sob os traços de uma humanidade comum que escondiam a sua glória de Ressuscitado, Cristo sobe aos céus e se senta à direita do Pai. Ele é o Senhor que reina agora com a sua humanidade na glória eterna do Filho de Deus e intercede incessantemente a nosso favor junto ao Pai. Envia-nos o seu Espírito e nos dá a esperança de estar com ele um dia, tendo-nos preparado um lugar. (BENTO XVI, 2005, p. 53-55).

O enunciado considerado supõe que a depreensão do sentido seja dada por meio das relações sincréticas entre os dois sistemas (verbal e visual) de que se compõe o folheto litúrgico (FLOCH, 1985). Assim, como estamos 
diante de um texto sincrético, devemos considerar a articulação entre as diferentes linguagens, verbais e visuais, dadas por meio da utilização da ilustração didática, tudo voltado para uma unidade de sentido.

A ilustração didática, um sistema semiótico plástico, ao operar a homologia com o sistema semiótico verbal do folheto litúrgico, confirma-o como um enunciado sincrético. Observamos, então, a presença de um sincretismo entre imagem e palavra. A estratégia enunciativa que sincretiza as diferentes linguagens de manifestação, numa totalidade de sentido, exerce-se de modo contratual.

No que concerne à coerção das imagens, percebemos que a ilustração didática, tal como nas Bíblias ilustradas, apresenta uma função pedagógica. As imagens têm como objetivo tornar esse discurso mais palatável, pois a coerção se dá pelo verbal, ao operacionalizar a colocação de categorias da crença a todo o momento.

No que diz respeito à imagem presente no enunciado do folheto, notamos a figurativização da temática da Ascensão de Cristo, por meio do cordeiro de Deus.

A Palavra Revelada é instituída como fonte primeira desse discurso, que tem por objetivo a realização do rito de atualização do sacrifício de Jesus na cruz.

O enunciado de folheto caracteriza-se, portanto, como um texto narrativo pautado pela progressão temporal e reduplicação mítica do discurso fundador, no caso, o relato bíblico de I Coríntios (I Coríntios 11, 23-26):

A “Ceia do Senhor" - [... ${ }^{23}$ Com efeito, eu mesmo recebi do Senhor o que vos transmiti: na noite em que foi entregue, o Senhor tomou o pão ${ }^{24}$ e, depois de dar graças, partiu-o e disse: "Isto é o meu corpo, que é para vós; fazei isto em memória de mim”. ${ }^{25}$ Do mesmo modo, após a ceia, também tomou o cálice, dizendo: "Este cálice é a nova Aliança em meu sangue; todas as vezes que dele beberdes, fazei-o em memória de mim. ${ }^{26}$ Todas as vezes, pois, que comeis desse pão e bebeis desse cálice, anunciais a morte do Senhor até que ele venha.

A referência ao discurso fundador confirma o caráter ritual da Santa Missa enquanto uma encenação. Temos, assim, por meio do enunciado do folheto, a construção de uma cenografia sacramental, na qual são colocadas 
em cena ações, gestos, palavras e acontecimentos para fazer presente um acontecimento destacado, no caso, a remissão à Santa Ceia, na condição de discurso fundador. O símbolo de comunhão eclesial estabelecido por Jesus com os seus discípulos na Última Ceia é recebido e ritualizado pela Igreja. A celebração eucarística constitui, portanto, a perpetuação eclesial dos símbolos instituídos por Jesus.

Verificamos, desse modo, uma tradição de continuidade espacial e temporal do rito da celebração eucarística, que teve seu início com a Última Ceia de Jesus, celebrada com os apóstolos na véspera de sua Paixão e Morte. Segue-se, a cada missa, uma cadeia ininterrupta de enunciações dessa prática ritual:

A última santa ceia de Jesus antes de sua paixão deu continuidade à sua prática anterior de refeições, pelo fato de que também lá a ceia, pela participação de Jesus, já se tornou antecipação, em forma de sinal, do senhorio vindouro de Deus. (PANNENBERG, 2009, p. 396).

A memória figurativa da Última Ceia transposta ao corpo textual e discursivo do rito eucarístico, ao supor a vigência de uma tradição, adota um protocolo, sendo perpetuada sem interrupção pela Igreja. Entendemos por vigência de uma tradição a continuidade temporal e espacial da realização desse rito, uma cadeia temporal ininterrupta de enunciações, de práticas rituais. Configura-se, diante disso, o rito da missa enquanto uma prática significante, pertencente, segundo os princípios da semiótica tensiva ao domínio da extensidade.

O ritual eucarístico acompanha um exemplo canônico de eficiência sintagmática. Compreendemos por eficiência sintagmática a organização sintagmática, aspectual e rítmica da sequência práxica (FONTANILLE, 2008, p. 48). Sendo assim, a eficiência do ritual da missa deriva de estrita aplicação de um esquema e de um percurso gerativo fixo, tal como procuramos demonstrar a seguir: 
Quadro 1 - Esquema do ritual da Santa missa

\section{MISSA}

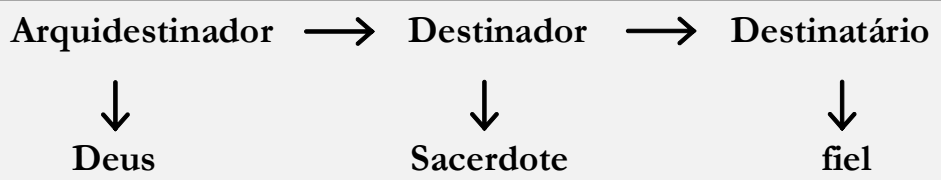

Tomemos, inicialmente, o seguinte mandamento de Jesus, discursivizado no enunciado do folheto como uma fórmula ritual: "Fazei isto em memória de mim".

Ressaltamos o caráter injuntivo dessa fórmula discursiva que tem por objetivo manipular os destinatários (apóstolos e sucessores) a prosseguir com a tradição da performance de ações práticas referentes à repetição dos gestos e palavras realizados por Jesus Cristo na Última Ceia. Essa manipulação visa, portanto, à celebração litúrgica pelos apóstolos e seus sucessores (mediadores - sacerdotes) do memorial da vida, morte, ressurreição de Cristo e intercessão dele junto ao Pai, em benefício dos fiéis. Remetemos à noção de actante coletivo em referência à comunidade de fiéis, pois essa prática ritual privilegia a atitude participativa dos fiéis na eucaristia, a fusão entre os membros do grupo. Temos, então, a fidelização religiosa dada por meio da experiência da Palavra:

Além de ser obra de Cristo, a liturgia é também uma ação da sua Igreja. Ela realiza e manifesta a Igreja como sinal visível de comunhão entre Deus e os homens por meio de Cristo. Empenha os fiéis na vida nova da comunidade. Implica uma ação "consciente, ativa e frutuosa” de todos. (PAULO II, 2000, p. 302).

No que concerne ao (PN), "sintagma elementar da sintaxe narrativa" (BARROS, 2002, p. 31), observamos a transformação principal operacionalizada por esse discurso como a ação de um sujeito sobre outro, para que este último possa manter-se em conjunção com o objeto valor "graça divina". 
Assim, o programa de base que rege esse discurso pode ser descrito como segue:

Quadro 2 - Programa narrativo de base

$$
\begin{gathered}
\text { PN de base: } \mathrm{S}_{1} \rightarrow \mathrm{S}_{2} \cap \mathrm{Ov} \\
\mathrm{S}_{1}=\text { ministro sacramental } \mathrm{S}_{2}=\text { cristão } \mathrm{Ov}=\text { graça divina }
\end{gathered}
$$

Observamos que o PN de base que rege esse enunciado apresenta o Sujeito $\mathrm{S}_{1}$ fazendo com que $\mathrm{S}_{2}$ permaneça em conjunção com o $\mathrm{O}_{\mathrm{v}}$ "graça divina", cujo investimento semântico e atribuição já teriam sido efetuados num $\mathrm{PN}$ de base, subentendido, que remonta à aquisição dos sacramentos de iniciação cristã do Batismo e Crisma.

Após a saudação inicial que, como todas as práticas rituais, começa por meio da fórmula ritual "Em nome do Pai, do Filho e do Espírito Santo. Amém", há a abertura do programa modal que visa à participação do fiel (actante coletivo) no rito eucarístico. Dispõe-se, assim, o programa modal que tem por objetivo preparar o actante sujeito coletivo a participar dos sagrados mistérios da redenção divina.

Logo após a saudação inicial, temos o ato penitencial, caracterizado pela presença de um programa modal de baixa intensidade, que tem por objetivo realizar a conversão do pecador, para que este entre novamente em um programa conjuntivo com o objeto-valor "graça divina". Temos como contrapartida o contraprograma dominante, o contraprograma disjuntivo do pecado promovido pelo maligno, enquanto destinador do mal. Assinalamos, assim, a disposição no enunciado de ambos os programas em favor do sujeito pecador disposto a continuar a prática ritual.

O PN estabelecido pelo destinador-manipulador para que o sujeito permaneça conjunto com tais valores corresponde ao fazer emissivo, que também poderíamos denominar continuativo. Nele, privilegiamos a dominância da temporalidade emissiva (parada da parada), responsável pelas experiências conjuntivas pautadas pela duração alongada. O antiprograma, realizado de modo implícito pelo antidestinador, demônio e más inclinações, corresponde ao fazer remissivo, à parada. Ao antiprograma, remetemos o conceito de surpresa, encarregado da ruptura da relação contratual entre destinador e destinatário e da interrupção do fluxo fórico. 
Notamos, ao longo do texto, a presença do destinador-manipulador tentando fazer com que o sujeito não pare, que ele siga o curso de restabelecimento da união original. Desse modo, o destinador-manipulador tenta assegurar a diretividade da direção estabelecida pelo âmbito contratual da fé e, para isso, faz uso de modulações de velocidade.

Toda ruptura pressupõe como coeficiente tensivo a alta velocidade, que poderia ocasionar a cisão do próprio sujeito e dos laços que o ligam ao sistema de valores considerado. Assim, para evitar a fratura da identidade entre sujeito e objeto e, consequentemente, a fratura do sistema de valores representado pela ideologia religiosa católica, o enunciador procede ao estabelecimento do prolongamento da relação conjuntiva, o que remete a uma experiência conjuntiva pautada pelo andamento desacelerado:

A desaceleração faz a duração durar de modo a dar tempo ao tempo. Por mais desconfortável que esteja a situação do sujeito, se este puder graduar seu tempo de acordo com certa programação, estabelecendo uma ordem de espera, é provável que obtenha as condições mínimas de segurança para conduzir seus passos seguintes. (TATIT, 2001, p. 117).

O domínio da religião não deseja que o objeto seja partido, para isso o crer faz uso do fazer emissivo. As atividades religiosas, devido a sua função pragmática, constituem-se como atividades desaceleradas. Já que o rito não pode ter como pressuposto a categoria surpresa, configura-se, nesse discurso, a opção pela parada da parada que visa segurar o tempo e fazer com que ele não se mova tão rápido. Esse momento desacelerado diante do mundo institui a presença de práticas para que o sujeito, ao se sentir o "senhor de seu próprio tempo", tenha as suas expectativas cumpridas.

Uma vez que o sujeito tenha adquirido o "poder" (a disposição de base, a fim de que esse possa integrar-se ao rito eucarístico), o actante sujeito necessita do objeto modal "saber", obtido mediante a liturgia da palavra. De acordo com Blanco (2008, p. 51-52), "este programa modal trata de atualizar a competência cognoscitiva dos participantes do rito. É um programa em que predomina a extensidade sobre a intensidade, o inteligível sobre o sensível".

Com a liturgia eucarística, damos início ao momento central da Santa Missa. “A Missa como 'realização' iterativa e multiplicativa do sacrifício de 
Jesus Cristo na cruz constitui o ponto de intensidade mais alto do desenvolvimento da prática ritual" (BLANCO, 2008, p. 52).

A liturgia eucarística apresenta uma tensão constante entre as modalidades do conseguir e do sobrevir. "Do ponto de vista figural, o sobrevir e o conseguir são regimes de valências regidos pelo andamento" (ZILBERBERG, 2007, p. 19):

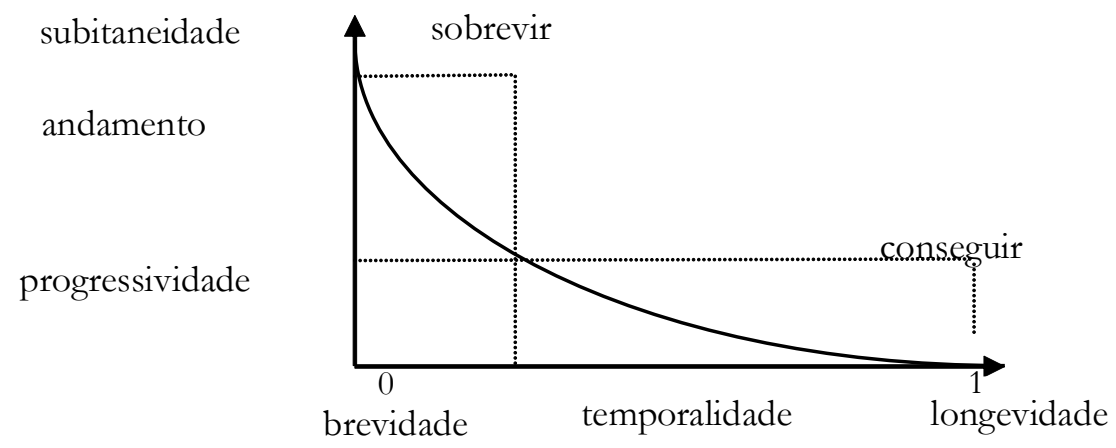

Figura 1 - As modalidades do conseguir e do sobrevir.

Consoante a implicação, isto é, a doxa, temos a consagração do pão e do vinho, momento segundo o qual tem lugar a transubstanciação $\sigma^{6}$ dessas espécies eucarísticas no corpo e sangue de Cristo, enquanto dogma para aquele que crê. De acordo com Zilberberg (2006), o acontecimento é o correlato objetal do sobrevir. O que, afinal, deveria ser comunicado ao enunciatário senão aquilo que lhe sobrevém e ao qual ele poderia crer, senão a partir do âmbito contratual da fé? O poder da palavra "Tomai, todos, e comei: isto é o meu Corpo, que será entregue por vós [...]. Tomai, todos e

6 "O Concílio de Trento resume a fé católica ao declarar: 'Por ter Cristo, nosso Redentor, dito que aquilo que oferecia sob a espécie do pão era verdadeiramente seu Corpo, sempre se teve na Igreja esta convicção, que o santo Concílio declara novamente: pela consagração do pão e do vinho opera-se a mudança de toda a substância do pão na substância do Corpo de Cristo Nosso Senhor e de toda a substância do vinho da substância do seu Sangue; esta mudança, a Igreja católica denominou-a com acerto e exatidão transubstanciação" (JOÃO PAULO II, 2000, p. 380). 
bebei: este é o cálice do meu Sangue” recai enquanto a intervenção de um acontecimento, que se sobrepõe a um enunciado de estado:

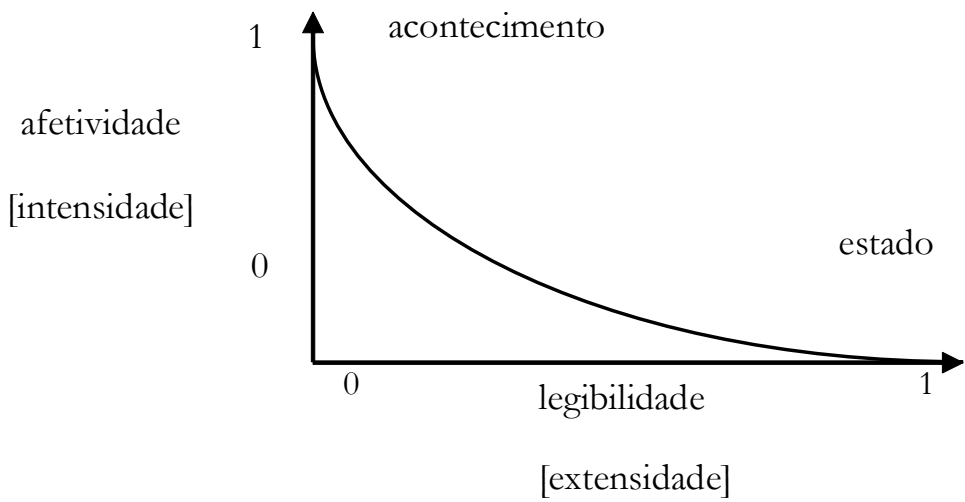

Figura 2 - Discurso do estado e do acontecimento (ZILBERBERG, 2006, p. 142)

O discurso do exercício, próprio à lógica implicativa, opõe-se ao discurso dito do acontecimento. $\mathrm{O}$ acontecimento instaura, nesse momento da missa, um programa dado como irrealizável, a que se contrapõe um contraprograma que leva a termo a sua realização mediante o âmbito contratual através da fé (ZILBERBERG, 2006, p. 148). A doxa é determinada pela desaprovação do excesso. Ao se situar no eixo do exercício, ou seja, ao conseguir e à lentidão, próprias à lógica implicativa, ela se contrapõe ao acontecimento, pautado pela exclamação própria ao sobrevir. Faz-se, assim, a necessidade de um tempo lento a fim de aplacar a perturbação sofrida pelos fiéis diante da emergência do acontecimento. Essa desaceleração se caracteriza mediante uma série de posturas próprias ao rito eucarístico: “os movimentos rituais são lentos, os gestos do sacerdote são pausados, as palavras são pronunciadas com clareza e sossego" (BLANCO, 2008, p. 53). A lentidão confirma o éthos solene, da graça e da solenidade. "O tempo se converte em vivência sensível, graças a essa desaceleração dos movimentos" (BLANCO, 2008, p. 53). A aceleração, no momento da comunhão, estabelece a parada, por isso, é exclusiva. A ela se sobrepõe a desaceleração dos gestos e ações sacramentais após a comunhão. A desaceleração, de âmbito 
participativo, reincorpora o sujeito, que pode, dessa maneira, retomar a continuidade no programa modal de participação do rito eucarístico. Temos, nessa prática cerimonial, a presença de uma cifra, de um ritmo que reflete o próprio sujeito absorto diante do mistério da fé. O enunciado, ao manifestar uma direção ascendente a um estado de aceleração máxima $[\mathrm{n}+1]$, orienta-se para a atenuação do impacto dado mediante a degressividade (projeção no campo de presença de cada vez menos mais [n-1]). Vejamos:

Missa: ascendência $\rightarrow$ pico da ascendência'!descendência

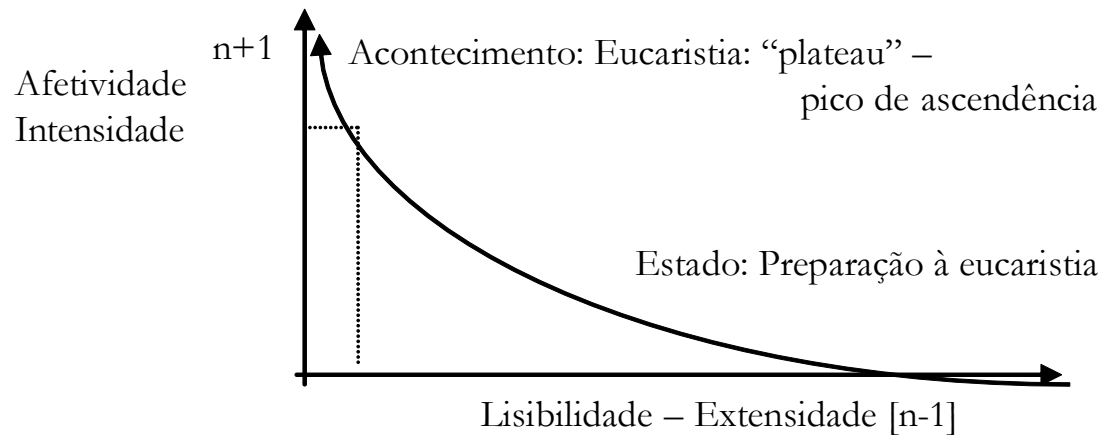

Figura 3 - Parte de preparação à eucaristia: ascendência’! pico da ascendência (Eucaristia)

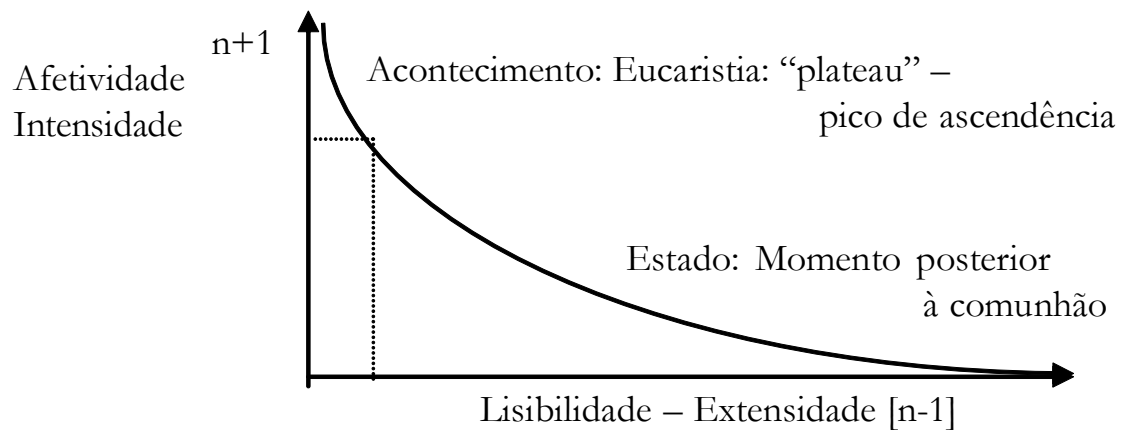

Figura 4 - Parte subsequente à eucaristia. 
Verificamos, pois, a projeção no enunciado do rito eucarístico de um estilo tensivo descendente, degressivo, que segue do "assomo" a "resolução" (ZILBERBERG, 2006, p. 15).

De acordo com Zilberberg (2006, p. 151), temos, representado no gráfico a seguir, o valor realizado V1, definido pela intersecção das valências v' e v", sobre a dimensão da intensidade. A orientação [V0 $\rightarrow$ V1] instaura uma orientação decrescente, de modo que v' depende da minimização da intensidade. Sobre a dimensão da extensidade, v" se situa na fase do restabelecimento da difusão. O acontecimento mediante a orientação [V1 $\rightarrow \mathrm{V} 0$ ] instaura, em contrapartida, uma orientação ascendente:

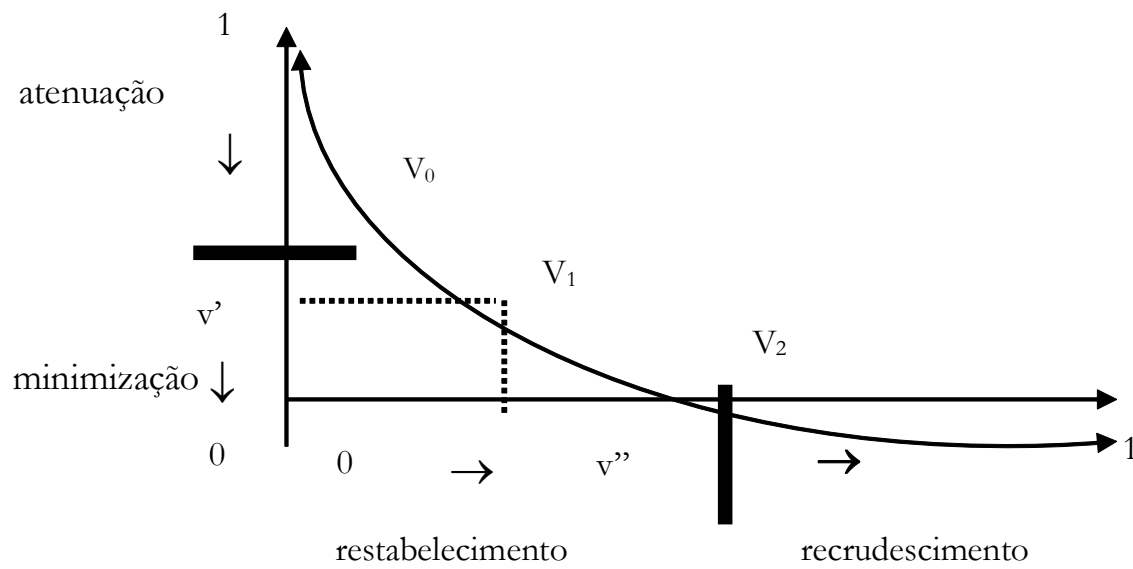

Figura 5 - Projeção dos valores sobre um arco de correlação inversa (ZILBERGERG, 2006, p. 151)

Voltando para as bases narrativo-discursivas da semiótica, vemos que, se compreendemos a missa como um relato dramatizado, composto de palavras, movimentos e gestos contínuos, em uma determinada conduta ritual, remetemos a corpos que ocupam um determinado espaço tensivo. Remetemos, assim, à noção de actorialização, temporalização e espacialização própria ao nível discursivo do percurso gerativo do sentido.

Tomamos como princípio os mecanismos de sintaxe discursiva (debreagem e embreagem) com a instauração no enunciado das categorias de pessoa, tempo e espaço. 
A presença do sagrado se efetua na noção de poder implicado nas palavras, o que remetemos aos usos da linguagem e às condições sociais de utilização das palavras. Notamos a força ilocucionária das expressões, cujo poder reside na autoridade concedida ao porta-voz autorizado, no caso, o padre.

Há uma retórica característica de todos os discursos institucionais: a autoridade concedida à tomada da palavra pelo porta-voz autorizado coincide com os limites delegados pela instituição. As características da linguagem dos quadros dos porta-vozes delegados de quaisquer instituições (ex. sacerdotes) derivam da posição que ocupam esses depositários da autoridade delegada:

Não basta dizer que o uso da linguagem por parte de um locutor determinado, numa dada situação, com seu estilo, sua retórica e sua pessoa toda socialmente marcada, agrega às palavras "conotações" associadas a um contexto particular, introduzindo assim no discurso o excedente de significado que lhe confere sua "força ilocucionária". O uso da linguagem, ou melhor, tanto a maneira como a matéria do discurso, depende da posição social do locutor que, por sua vez, comanda o acesso que se lhe abre à língua da instituição, à palavra oficial, ortodoxa, legítima. (BOURDIEU, 1998, p. 87).

O poder das palavras reside não apenas no fato de terem sido proferidas por aquele que seria o "portador" delas, mas "na medida em que sua fala concentra o capital simbólico acumulado pelo grupo que the conferiu o mandato e do qual ele é, por assim dizer, o procurador" (BOURDIEU, 1998, p. 89).

O princípio de eficácia simbólica compreende: "a relação entre as propriedades do discurso, as propriedades daquele que o pronuncia e as propriedades da instituição que o autoriza a pronunciá-lo" (BOURDIEU, 1998, p. 89).

Na missa, há um contrato de delegação de vozes que dá ao sacerdote o monopólio da manipulação dos bens de salvação. Esse contrato se manifesta no adequado cumprimento do código da liturgia (gestos e palavras sacramentais), bem como por meio da presença dos atributos simbólicos 
do magistério ${ }^{7}$ (a batina, o latim, os lugares e os objetos consagrados).

"A magia performativa do ritual funciona completamente apenas na medida em que o procurador religioso, incumbido de realizá-lo em nome do grupo, age como uma espécie de médium entre o grupo e ele próprio" (BOURDIEU, 1998, p. 95).

A “eficácia simbólica das palavras" é determinada pelo reconhecimento da autoridade do enunciador por parte do enunciatário:

Em sua celebração litúrgica, a assembleia inteira desempenha o papel de "liturgo", cada um segundo a sua função. O sacerdócio batismal é de todo o corpo de Cristo. Mas certos fiéis são ordenados pelo sacramento da Ordem para representar Cristo como cabeça do corpo. (JOÃO PAULO II, 2000, p. 334).

Temos a actorialização característica do enunciado do folheto segundo a delimitação entre o que seria pronunciado apenas pelo portador autorizado, no caso, o padre, e as partes da missa a serem pronunciadas pelos fiéis. Essa disposição e delimitação de papéis definidos aparecem discursivizadas na própria composição diagramática do folheto. A letra "P" se refere à enunciação atribuída ao sacerdote e a letra " $T$ ", às respostas dirigidas pela comunidade. Essas respostas também apresentam destaque em negrito:

\section{Oração eucarística}

P. O Senhor esteja conosco

\section{T. Ele está no meio de nós}

P. Corações ao alto

\section{T. O nosso coração está em Deus.}

${ }^{7}$ Entendemos por magistério a "palavra latina que significa 'autoridade para ensinar'. De acordo com a doutrina católica, essa autoridade é conferida pelo Papa, ao sucessor de São Pedro e o chefe da Igreja, e aos Bispos em conjunto e em união com o Papa. Essa autoridade de ensinar é, em alguns casos, infalível e assim exige dos fiéis cristãos o consentimento da fé. Por outro lado, essa autoridade, mesmo quando não explicitamente infalível, expressa o autêntico ensinamento católico cristão e exige do fiel cristão a leal submissão da vontade e do intelecto" (LOWERY, 1999, p. 93). 


\section{P. Demos graças ao Senhor, nosso Deus. \\ T. É nosso dever e salvação.}

O narrador (implícito ao enunciado), por meio de uma debreagem enunciativa de segundo grau, delega voz aos actantes do enunciado (interlocutor e interlocutário), instaurando o diálogo. Observamos o estabelecimento do simulacro de uma interação ritualística sacramental por intermédio da distribuição do enunciado em uma estrutura de enunciação de fórmulas discursivas e sintagmas cristalizados. As questões possuem a forma imperativa a partir do emprego de fórmulas cristalizadas pertencentes à tradição discursiva da comunidade. Simula-se um jogo de vozes (a do interlocutor e a do interlocutário) que viabiliza o simulacro de um efeito dialogal.

Mediante a instauração dessa cena, obtém-se o efeito de sentido de distância maximizada entre enunciação e enunciado. Esse jogo de vozes entre actantes do enunciado constrói uma ilusão de realidade, a ilusão de uma situação real de enunciação do rito eucarístico.

Interlocutor (sacerdote, voz autorizada) e interlocutário (comunidade de fiéis) enunciam-se por meio do uso do pronome pessoal reto "nós". Esse "nós" configura-se como um "nós" inclusivo (eu + você + eles = nós, esta comunidade religiosa), nessa debreagem enunciativa de segundo grau.

Viabiliza-se o simulacro de um jogo de vozes, o "nós" que enuncia e o "nós" que responde, com a utilização da mesma pessoa gramatical: um nós generalizado, de toda pessoa, lugar e espaço:

P. Irmãos e irmãs, elevemos nossas preces ao Pai, pedindo-lhe a graça da fidelidade no testemunho de Cristo e na unidade entre os cristãos, rezando juntos:

\section{T. Enviai-nos, Senhor, vosso Espírito de amor!}

Nesse último caso, afirma-se pela utilização do pronome "vós" a distância entre o sujeito "nós" (comunidade eucarística) e o arquidestinador divino, intermediada pelo sacerdote: "Lembrai-vos, ó pai dos vossos filhos".

Verifica-se, também, enquanto argumento de autoridade que tem por objetivo validar a prática do sacrifício eucarístico, a instauração de uma debreagem enunciativa de segundo grau que delega voz ao próprio Cristo e 
encontra-se disposta diagramaticamente em caixa alta. Essa sequência injuntiva remete ao caráter sacrifical do corpo e sangue de Cristo, figurativizada sob as espécies eucarísticas do pão e do vinho. A palavra divina institui-se no enunciado como um performativo absoluto:

\section{TOMAI, TODOS, E COMEI: ISTO É O MEU CORPO, QUE SERÁ ENTREGUE POR VÓS [...]. TOMAI, TODOS E BEBEI: ESTE É O CALÍCE DO MEU SANGUE, O SANGUE DA NOVA E ETERNA ALIANÇA, QUE SERÁ DERRAMADO POR VÓS E POR TODOS, PARA REMISSÃO DOS PECADOS, FAZEI ISTO EM MEMÓRIA DE MIM.}

Por sua vez, observa-se a presença da primeira pessoa do plural por meio do vocativo que afirma o chamamento do sujeito dado por meio do sintagma cristalizado: "Recebei, ó Senhor, a nossa oferta". O "nós", representado por meio do interlocutor (comunidade eucarística), dirige-se, em oração, a Cristo, Nosso Senhor. Isso reforça o caráter invocativo do sujeito em falta, elidido e disposto numa posição de inferioridade.

O enunciado do folheto operacionaliza uma debreagem temporal enunciativa, uma vez que "se projetam no enunciado os tempos do sistema enunciativo" (FIORIN, 2002, p. 147). Nesse nível, a debreagem actorial será dita de segundo grau, por se encontrar relacionada à categoria do interlocutor, delegada do narrador implícito e instaurada na forma de diálogo.

Estando construído dentro do sistema enunciativo, o enunciado do folheto litúrgico pauta-se em relação ao "agora", em concomitância ao marco referencial presente. Relaciona-se, portanto, a um momento de referência presente, idêntico ao momento da enunciação.

O tempo verbal característico desse discurso é o presente omnitemporal ou gnômico, fato que o constitui como um enunciado válido para qualquer lugar ou época histórica e o caracteriza como um enunciado próprio da esfera de circulação do discurso religioso, utilizado para a enunciação de verdades eternas.

O texto do folheto litúrgico, ao ser organizado ao redor da instância do "aqui", simula uma cena enunciativa por meio da instauração do diálogo. O espaço linguístico é expresso no enunciado do folheto mediante a utilização dos advérbios de lugar. Observamos a presença do advérbio enunciativo 
(aqui): “T. Em comunhão com toda a Igreja aqui estamos!”. “Aqui” marca o espaço da cena enunciativa, sendo que este assinala o espaço do nós, da comunidade eucarística que se dirige em direção superativa ao vós arquienunciador divino.

A cena dialógica caracteriza-se pela irreversibilidade de posições enunciativas: Jesus Cristo/ Espírito Santo (lá), comunidade de fiéis (aqui) e o sacerdote como intermediário entre os planos espaciais (aqui) e o espiritual (lá). O enunciado constrói, por meio da irreversibilidade, uma proxêmica dada na ordem da estabilidade ${ }^{8}$. A estaticidade, que permeia a formação ideológica considerada, produz o simulacro de um mundo estabilizado com lugares definidos.

A figura de Jesus Cristo/Espírito Santo, ao se instituir na ordem do inefável, transcende os limites humanos e consolida a isotopia da santidade.

Temos, portanto, a espacialização dada na ordem da verticalidade, pautada pela direção superativa no eixo da verticalidade. O olhar da verticalidade constrói o plano espiritual a partir do ponto de vista eufórico, estabelecendo o "alto" como categoria eufórica. Seu olhar, mediado pela instância intermediadora do agente religioso, estabelece-se por meio do "baixo" (disfórico) para o "alto" (eufórico):

\section{ORAÇÃO APÓS COMUNHÃO}

P. Oremos (silêncio): Deus eterno e todo-poderoso, que nos concedeis conviver na terra com as realidades do céu, fazei com que nossos corações se voltem para o alto, onde está junto de vós a nossa humanidade. Por Cristo, nosso Senhor.

T. Amém.

Por meio desse exemplo, adquirimos a visão do baixo disfórico, do sujeito em falta, um sujeito que não é, mas pode vir a ser por meio da invocação oracional pautada na fé.

A disposição espacial própria ao rito eucarístico se desdobra na demarcação entre o espaço sagrado e o espaço profano. Retomamos a

8 "A proxêmica é uma disciplina - ou melhor, um projeto de disciplina - semiótica que visa a analisar a disposição dos sujeitos e dos objetos no espaço e, mais particularmente, o uso que os sujeitos fazem do espaço para fins de significação" (GREIMAS; COURTÉS, 2008, p. 395). 
prevalência das operações de triagem (ZILBERBERG, 2004), que caracterizam a instituição de um espaço ritual pautado por um deslocamento horizontal, segundo o qual se distribui "uma região sagrada, separada e protegida de tudo aquilo que a rodeia, e uma região profana, ou não sagrada acessível a todas as pessoas" (BLANCO, 2008, p. 48).

Verificamos um acento de valor apreciativo, transmitido por uma entonação expressiva e afetiva, conforme a qual o espaço sagrado remete a um acento de intensidade e o espaço profano se caracteriza pela extensidade. Remetemos a tonicidade ou a atonia das percepções, ao tipo perceptivo do foco e da apreensão (ZILERBERG; FONTANILLE; 2001, p. 129). Ao tipo perceptivo do foco (espacialização fechada), associamos o espaço sagrado; ao tipo perceptivo da apreensão (espacialidade aberta), o espaço profano.

Vejamos o seguinte esquema (BLANCO, 2008, p. 49, tradução nossa)'

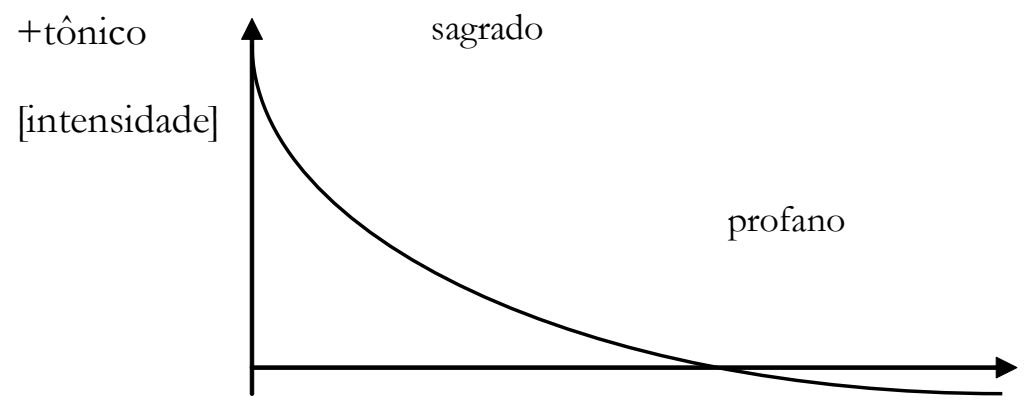

+átono

[extensidade]

Figura 6 - Oposição entre o sagrado e o profano.

9 Ressaltamos que se fizeram necessárias algumas restrições ao pensamento de Blanco (2008), a partir de Zilberberg (2006). Embora Blanco (2008) se utilize da oposição entre "acento tônico", em referência à intensidade, e "ausência de acento", no que tange à extensidade, optamos por substituí-los, respectivamente, no gráfico apresentado, pelos termos "tônico" e "átono", tal como utilizados por Zilberberg (2006), a fim de que não tivéssemos incongruências na tese. 
Dentro do templo, podemos considerar, ainda, uma gradação da tonicidade do espaço sagrado. A tonicidade confere um determinado "acento de sentido" a cada um dos segmentos que compõe o discurso. O espaço do templo e sua disposição configuram-se como um discurso que fala a seus fiéis (BLANCO, 2008, p. 49). Consideramos a disposição das quatro partes das quais se constitui o templo, tido enquanto espaço sagrado das práticas rituais católicas: sacrário, presbitério (altar), naves e átrio.

a) Sacrário (tabernáculo): presença das espécies consagradas (corpo de Cristo);

b) Presbitério (altar): centro da Igreja, nele se faz presente o Sacrifício da Cruz sob os sinais sacramentais.

c) Naves: disposição dos fiéis;

d) Átrio: pátio interno (trânsito entre o sagrado e o profano).

Observemos como se configura a gradação do espaço tensivo do templo sob o parâmetro da tonicidade. Retomamos e ampliamos o gráfico original apresentado por Blanco (2008, p. 49):

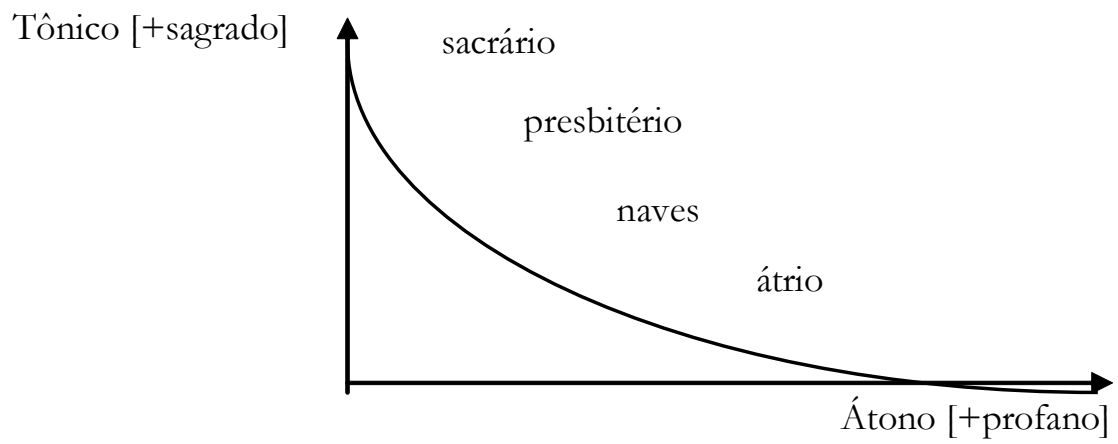

Figura 7 - Gradação do espaço tensivo no templo

$\mathrm{O}$ átrio, passagem entre o sagrado e o profano, apresenta um acento de sentido débil, quase nulo. As naves constituem o espaço mais amplo do templo, onde se situam os fiéis (actantes coletivos) dispostos à participação no rito da missa. Consolida-se a atitude de participação dos fiéis, dada mediante um conjunto de posturas e disposições com os quais esses se colocam diante do sagrado. 
Entre essas atitudes, podemos destacar a presença de momentos contemplativos, de silêncio, de cânticos etc., determinada no enunciado do folheto por meio de marcas enunciativas (BLANCO, 2008, p. 50). Vejamos:

\section{HINO DE LOUVOR (preferencialmente cantado)}

P. Glória a Deus nas alturas,

T. e paz na terra aos homens por Ele amados [...].

\section{ORAÇÃO}

P. Oremos (silêncio): Ó Deus todo poderoso, a ascensão de vosso filho já é nossa vitória [...].

O presbitério destina-se ao celebrante (porta-voz autorizado) e seus acompanhantes. $\mathrm{O}$ acento de sentido adquire nesse espaço um grau ainda mais alto de tonicidade. O tabernáculo, lugar das espécies consagradas, constitui-se como um lugar sacratíssimo por excelência, lugar em que se consolida a totalidade culminante no âmbito total do sagrado (BLANCO, 2008, p. 50).

\section{Considerações Finais}

A formação discursiva, como sistema de crenças e aspirações, fundado em figuras e temas de determinado discurso, e a escolha de recursos relativos à gramática da língua se refletem na incorporação de um éthos dogmático, o que permite caracterizar os enunciados de fidelização, definindo-os segundo os parâmetros da "prática religiosa católica", como gêneros de fronteira entre a divulgação e a fidelização religiosa, que julgamos por bem nomeálos como pertencentes à “experiência da Palavra”. Esses gêneros são voltados para arrebanhar mais e mais fiéis no exercício da própria fidelização. Ao éthos da resignação associamos o sujeito (fiel) dominado e subjugado pela instituição religiosa e as suas práticas instituídas sob a aparência da unidade. Por sujeito resignado, está o sujeito submisso a essas práticas ritualísticas e que a elas deve se submeter a fim de obter a salvação. 


\section{Anexos}

Folheto de Missa: Semanário Litúrgico Catequético. O Povo de Deus em São Paulo, de 16 de maio de 2010.

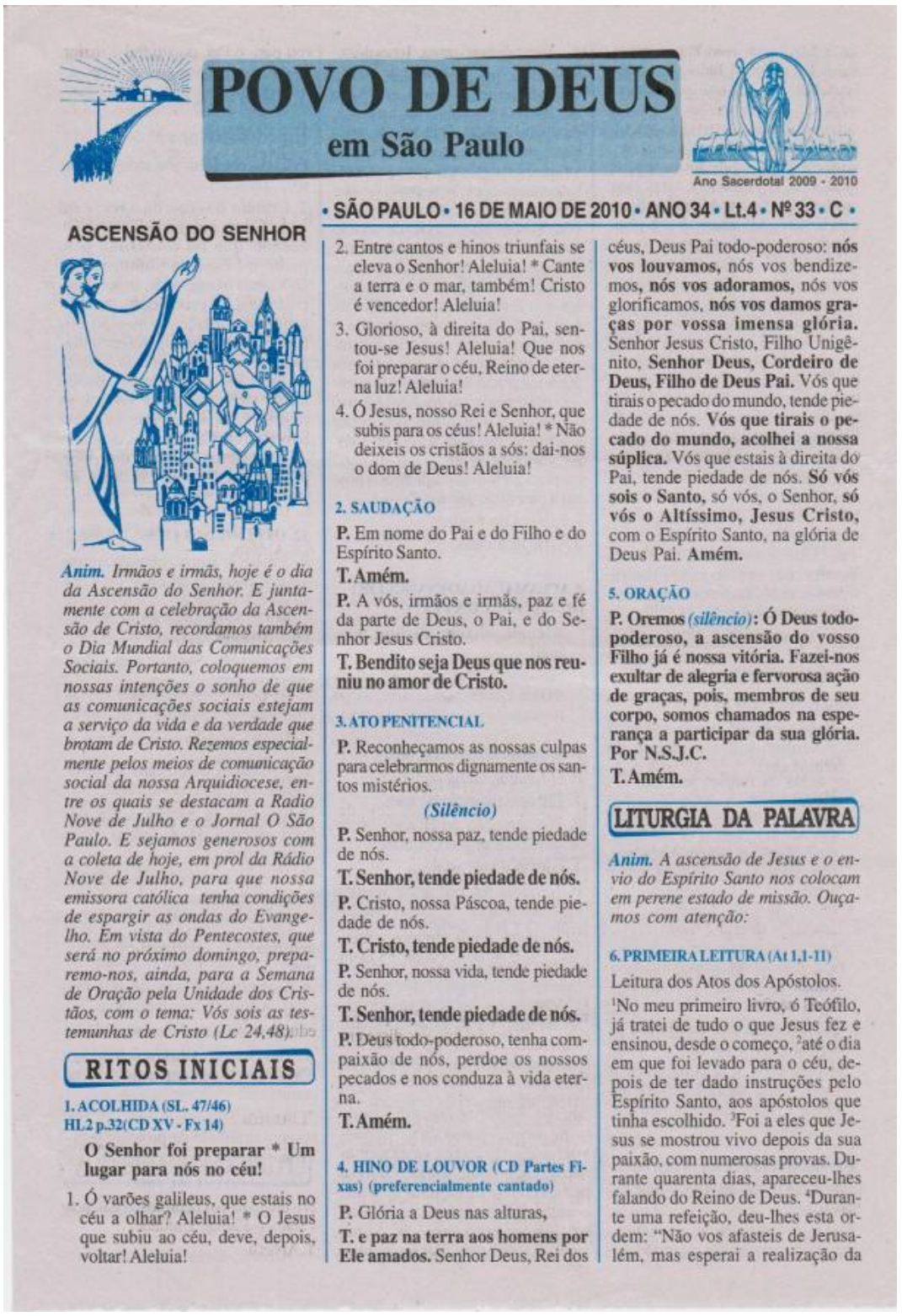


promessa do Pai, da qual vós me ouvistes falar: ${ }^{56} \mathrm{~J}$ oão batizou com água; vós, porém, sereis batizados com o Espírito Santo, dentro de poucos dias"." "Entâo os que estavam reunidos perguntaram a Jesus: "Senhor, é agora que vais restaurar o Reino em Israel?" ' Jesus respondeu: "Não vos cabe saber os tempos e os momentos que o Pai determinou com a sua própria autoridade. ${ }^{8}$ Mas recebereis o poder do Espírito Santo que descerá sobre vós, para serdes minhas testemunhas em Jerusalém, em toda a Judéia e na Samaria, e até os confins da terra", "Depois de dizer isto, Jesus foi levado ao céu, à vista deles. Uma nuvern o encobriu, de forma que seus olhos não mais podiam vê10. "Os apóstolos continuavam olhando para o céu, enquanto Jesus subia. Apareceram entâo dois homens vestidos de branco, "que Ihes disseram: "Homens da Galiléia, por que ficais aqui, parados, olhando para o céu? Esse Jesus que vos foi levado para o céu, virá do mesmo modo como o vistes partir para o céu". Palavra do Senhor.

\section{T. Graças a Deus.}

\section{SALMO RESPONSORIAL 46,47} (HL2 p. 77-79 - CD XV Fx 2

Batei palmas, povos todos, * o Senhor subiu ao toque da trombeta!

1. Povos todos do universo, batei palmas, " gritai a Deus aclama. çôes de alegria! * Porque sublime é o Senhor, o Deus Altíssimo, * o soberano que domina toda a terra.

2. Por entre aclamaçōes Deus se elevou, * o Senhor subiu ao toque da trombeta. * Salmodiai ao nosso Deus ao som da harpa, * salmodiai ao som da harpa ao nosso Ret

3. Porque Deus é o grande Rei de toda a terra, " ao som da harpa acompanhai os seus louvores! * Deus reina sobre todas as naçốes, * está sentado no seu trono glorioso.

8. SEGUNDA LETTURA - EF 1, 17-23

Leitura da Carta de São Paulo aos Efésios.

Irmãos: $7 \mathrm{O}$ Deus de nosso Senhor Jesus Cristo, o Pai a quem perten- ce a glória, vos dê um espírito de sabedoria que vo-ló revele e faça verdadeiramente conhecer. ${ }^{15}$ Que ele abra o vosso coraçẫo à sua luz. para que saibais qual a esperança que o seu chamamento vos dá, qual a riqueza da glória que está na vossa herança com os santos, ${ }^{10} \mathrm{e}$ que imenso poder ele exerceu em favor de nós que cremos, de acordo com a sua ação e força onipotente. ${ }^{20}$ Ele manifestou sua força em Cristo, quando o ressuscitou dos mortos e o fez sentar-se à sua direita nos céus, ${ }^{21}$ bem acima de toda a autoridade, poder, potência, soberania ou qualquer titulo que se poss: mencionar não somente neste mundo, mas ainda no mundo futuro. "Sim, ele pôs tudo sob os seus pés e fez dele, que está acima de tudo. a Cabeça da Igreja, ${ }^{23} q u e$ é o seu corpo, a plenitude daquele que possui a plenitude universal.

- Palavra do Senhor.

\section{T. Graças a Deus.}

\section{ACLAMAÇÃO AO EVANGELHO} (HL. 2, p. 108 - CD XV Fx 7)

Aleluia, aleluia, aleluia, aleluia!

Ide ao mundo, ensinai aos povos todos; / convosco estarei, todos os dias.

\section{EVANGELHO (Le 24, 46-53)}

P. O Senhor esteja convosco.

\section{T. Ele está no meio de nós.}

P. Proclamaçăo do Evangelho de Jesus Cristo segundo Lucas.

T. Glória a vós, Senhor.

P. Naquele tempo, disse Jesus a seus discípulos: ${ }^{2++}$ Assim está escrito: O Cristo sofrerá e ressuscitará dos mortos ao terceiro dia ${ }^{47} \mathrm{e}$ no seu nome, serăo anunciados a conversão $\mathrm{e} o$ perdão dos pecados a todas as naçōes, começando por Jerusalemb arvos sereis testemunhas de tudo isso. "Eu enviarei sobre vós aquele que meu Pai prometeu. Por isso, permanecei na cidade, até que sejais revestidos da força do alto". "Entâo Jesus levouos para fora, até perto de Betânia. Ali ergueu as mãos e abençoou-os. s'Enquanto os abençoava, afastouse deles e foi levado para o céu. "Eles o adoraram. Em seguida voltaram para Jerusalém, com grande alegria. ${ }^{5} \mathrm{E}$ estavam sempre no
Templo, bendizendo a Deus. - $\mathrm{Pa}$ lavra da Salvaçāo.

\section{T. Glória a vós, Senhor.}

\section{PROFISSÃO DE FE}

P. Creio em Deus Pai todo-poderoso,

T. Criador do céu e da terra; e em Jesus Cristo, seu único Filho, nosso Senhor; que foi concebido pelo poder do Espírito Santo; nasceu da Virgem Maria, padeceu sob Pôncio Pilatos, foi crucificado, morto e sepultado; desceu à mansão dos mortos; ressuscitou ao terceiro dia; subiu aos céus, está sentado à direita de Deus Pai todo-poderoso, donde há de vir a julgar os vivos e os mortos. Creio no Espírito Santo, na Santa Igreja Católica: na comunhão dos santos; na remissão dos pecados; na ressurreição da carne; na vida eterna. Amém.

\section{ORAÇĀO DOS FIÉis}

P. Irmãos e irmãs, elevemos nossas preces ao Pai, pedindo-the a graça da fidelidade no testemunho de Cristo e da unidade entre os cristāos, rezando juntos:

T. Enviai-nos, Senhor, vosso Espírito de amor!

1. Enriquecei a Igreja com a força que levou os Apóstolos a testemunharem o Cristo.

2. Fortalecei os cristāos no testemunho do Cristo ressuscitado.

3. Guardai na comunhão os que buscam com sinceridade o Cristo ressuscitado.

4. Apagai as divisōes que dilaceram o corpo eclesial e dificultam a uniâo entre os cristãos.

5. Fazei-nos apóstolos da comunhão e do amor sem fronteiras.

6. Uni nossas forças no testemunho da honestidade e do bem.

(Outras preces da comunidade)

P. Tudo isso vos pedimos, 6 Pai, por Cristo, fonte de comunhão e de fraternidade.

T.Amém.

\section{UTURGIAEUCARISTICA}

\section{APRESENTAC̣ÃODASOFERENDAS} (CD XV Fx 12 )

Aleluia, aleluia, aleluia! 
1. Recebe, 6 Pai, esta nossa oblação, * de nossas faltas concede o perdão, * por Jesus Cristo, que é nosso irmão. Aleluia!

Aleluia, aleluia, aleluia!

2. As nossas penas, o nosso labor, * nossa alegria e nosso amor, * por Jesus Cristo, recebe, Senhor. Aleluia!

14. ORAÇÃO SOBRE AS OFERENDAS

P. Orai, irmãos e irmấs..

T. Receba o Senhor por tuas mãos este sacrificio, para glória do seu nome, para nosso bem e de toda a santa Igreja.

P. $\sigma$ Deus, nós vos apresentamos este sacrifficio para celebrar a admirível ascensão do vosso Filho. Concedei, por esta comunhẫo de dons entre o céu e a terra, que nos elevemos com ele até a pátria celeste. Por Crísto, nosso Senhor.

T.Amém.

\section{ORAÇÃOEUCARÍSTICAI}

(Pref. Ascensão I, MR p. 426)

P. O Senhor esteja convosco.

T. Ele está no meio de nós.

P. Coraçōes ao alto.

T. O nosso coração está em Deus.

P. Demos graças ao Senhor, nosso Deus.

T.É nosso dever e nossa salvação.

P. Na verdade, é justo e necessário, é nosso dever e salvação darvos graças, sempre e em todo o lugar, Senhor, Pai, santo, Deus etemo e todo-poderoso. Vencendo o pecado e a morte, vosso Filho Jesus, Rei da Glória, subiu hoje ante os anjos maravilhados ao mais alto dos ceus. E tornou-se o mediador entre vós, Deus, nosso Pai, e a humanidade redimida, juiz do mundo e senhor do universo. Ele, nossa cabeça e princípio, subiu aos céus, năo para afastar-se de nossa humildade, mas para dar-nos a certeza de que nos conduziráa à glória da imortalidade. Por essa razão, transbordamos de alegria pascal, e aclamamos yossa bondade, cantando (dizendo) a uma só voz:

T. Santo, Santo, Santo...

CP. Pai de misericórdia, a quem sobem nossos louvores, nós vos pedimos por Jesus Cristo, vosso Fithoe Senhor nosso, que abencoeis t? estas oferendas apresentadas ao vosso altar.
T. Abençoai nossa oferenda, 0 Senhor!

Nós as oferecemos pela vossa Igreja santa e católica: concedei-Ihe paz e proteção, unindo-a num só corpo e governando-a por toda a terra. Nós as oferecemos também pelo vosso servo, o Papa Bento, por nosso Bispo Odilo, e por todos os que guardam a fé que receberam dos apóstolos.

T. Conservai a vossa Igreja sempre unida.

1C. Lembrai-vos, ó Pai, dos vossos filhos e fillhas.... e de todos os que circundam este altar, dos quais conheceis a fidelidade e a dedicação em vos servir. Eles vos oferecem conosco este sacrificio de louvor por Sí e por todos os seus, e elevam a vós as suas preces para alcançar o perdão de suas faltas, a segurança em suas vidas e a salvação que esperam.

T. Lembrai-vos, ó Pai, de vossos filhos!

2C. Em comunhẫo com toda a Igre$\mathrm{ja}$, celebramos o dia santo em que vosso Filho único elevou à glória da vossa direita a fragilidade da nossa carne. Veneramos também a Virgem Maria e seu esposo São José, os santos Apóstolos e Mártires: Pedro e Paulo, André,.. e todos os vossos Santos. Por seus méritos e preces concedei-nos sem cessar a vossa proteção.

T. Em comunhão com toda a Igreja aqui estamos!

CP. Recebei, 6 Pai, com bondade, a oferenda dos vossos servos e de toda a vossa familia; dai-nos sempre a vossa paz, livrai-nos da condenação e acolhei-nos entre os vos. sos eleitos.

CC. Dignai-vos, ó Pai, aceitar e santificar estas oferendas, a fim de que se tornem para nós o Corpo e o Sangue de Jesus Cristo vosso Fitho e Senhor nosso.

T. Santificai nossa oferenda, 6 Senhor!

Na noite em que ia ser entregue, ele tomou o pão em suas mãos, elevou os olhos a vós, ó Pai, deu graças e o partiu e deu a seus discipulos, dizendo:

TOMAI, TODOS, E COMEI: ISTO É O MEU CORPO, QUE SERÁ ENTREGUE POR VÓS.
Do mesmo modo, ao fim da ceia, ele tomou o cálice em suas mãos, deu graças novamente, e o deu a seus discípulos, dizendo:

TOMAI, TODOS, E BEBEI ESTE É O CÁLICE DO MEU SANGUE, O SANGUE DA NOVA E ETERNA ALIANCA, OUE SERÁ DERRAMADO POR VÓS E POR TODOS, PARA REMISSẢO DOS PECADOS. FAZEI ISTO EM MEMÓRIA DE MIM.

Eis o mistério da fé!

T.Salvador do mundo, salvai-nos, vós que nos libertastes pela cruz e ressurreição.

CC. Celebrando, pois, a memória da paixão do vosso Filho, da sua ressurreiçāo dentre os mortos e gloriosa ascensão aos céus, nós, vossos servos, e também vosso povo santo, vos oferecemos, ó Pai, dentre os bens que nos destes, o sacrifício perfeito e santo, pão da vida eterna e cálice da salvação.

T. Recebei, óSenhor, a nossa oferta! Recebei, 6 Pai, esta oferenda, como recebestes a oferta de Abel, o sacrifício de Abraão e dos dons de Melquisedeque.

Nós vos suplicamos que ela seja levada à vossa presença, para que, ao participarmos deste altar, recebendo o Corpo e o Sangue de vosso Filho, sejamos repletos de todas as graças e bênçãos do céu.

T. Recebei, 6 Senhor, a nossa oferta!

3C. Lembrai-vos, ó Pai, dos vossos filhos e filhas N. e N. que partiram desta vida, marcados com o sinal da fé. A eles, e a todos os que adormeceram no Cristo, concedei a felicidade, a luz e a paz.

T. Lembrai-vos, 6 Pai, dos vossos filhos!

4C. E a todos nós pecadores, que confiamos na vossa imensa misericórdia, concedei, nảo por nossos meritos, mas por vossa bondade, o convivio dos Apóstolos e Mártires: João Batista e Estevão, Matias e Barnabé ... e todos os vossos santos. Por Cristo, Senhor nosso.

\section{T. Concedei-nos o convívio dos} eleitos!

Por ele não cessais de criar e santificar estes bens e distribui-los entre nós.

CP ou CC. Por Cristo, com Cristo e em Cristo, a vós. Deus Pai todopoderoso, na unidade do Espírito 
Santo, toda a honra e toda a glória, agora e para sempre.

T.Amém.

\section{RITO DA COMUNHÃO}

16. PAI NOSSO

17. CANTO DE COMUNHÃO SL. 68(67) (CD - X - Fx 17)

O Senhor subiu ao céu, aleluia, aleluia! (bis)

1. Levanta-se Deus, cadê os inimigos? * Na sua presença perecem os iníquos! * São como fumaça que desaparece, * são cera no fogo, que logo derrete!

2. Os justos se alegram diante de Deus * cantai ao Senhor, vibrai, filhos seus! * Abri o caminho ao grão-cavaleiro, * dançai diante dele, Senhor e justiceiro.

3. Dos órfãos é Pai, das viúvas juiz, * em sua morada só ele é quem diz: " quem 'stava sozinho, famflia encontrou, * quem 'stava oprimido, tua mão libertou!

4. À frente do povo saíste, 6 Deus, * Os céus gotejaram, a terra tremeu; * Na sua presença se abala o Sinai, "é Deus que avança, que avança vai!

5. U'a chuva abundante do céu derramaste. * $E$ tua herança exausta saciaste; * fizeste em tua paz viver teu rebanho, * e os necessitados tiveram seu ganho.

\section{ORAÇÃO APÓS A COMUNHÃO}

P. Oremos (silêncio): Deus eterno e todo-poderoso, que nos concedeis conviver na terra com as realidades do céu, fazei que nossos corações se voltem para o alto, onde está junto de vós a nossa humanidade. Por Cristo, nosso Senhor.

T.Amém.

\section{RITOS FINAIS}

T. Ó São Paulo,/Patrono de nossa Arquidiocese, / discípulo e missionário de Jesus Cristo: / ensina-nos a acolher a Palavra de Deus/e abre nossos olhos à verdade do EvangeIho./Conduze-nos ao encontro com Jesus, / contagia-nos com a fé que te animou/e infunde em nós corageme ardor missionário, / para testemunharmos a todos/que Deus habita esta Cidade imensa /e tem amor pelo seu povo! / Intercede por nós e pela Igreja de São Paulo, /ó santo apóstolo de Jesus Cristo! Amém

\section{râdio AM $1600 \mathrm{kHz}$ 9dejulho tocandosuavidamelhor}

A Rádio Nove de Julho agradece sua contribuição por meio da coleta desta Missa. Assim, se fortalece a missão de divulgar o Evangelho de Cristo e a cultura do amor.

\section{$1^{\circ}$ CONGRESSO DE LEIGOS DA ARQUIDIOCESE DE SÃO PAULO}

Oficina: Vida e Missẫo do Leigo no mundo da comunicaçāo social. Oficina: Vida e Missão do Leigo na promoção da caridade.

Os leigos católicos têm um vasto espaço para a evangelização e atuação nos vários campos, níveis e competências da imprensa e da comunicação social e do serviço à caridade em relação aos mais necessitados da cidade, para que sejam permeados pela luz, a verdade e o Evangelho de Cristo. Quais desafios? Como podem se organizar? Como buscar formação cristã católica específica?

Informe-se na sua Paróquia.

No dia $\mathbf{3 0}$ de maio, domingo da Santíssima Trindade,

a nossa Arquidiocese comemora o encerramento do ano sacerdotal e o jubileu dos padres de 2009-2010 com a Missa. na Catedral, às 15 horas.

MÚSICAS: - CD XV • CO Cantos e Orações • (HL. 2) Hinário Litúrgico
LEITURAS DA SEMANA: de 17 a 23 de MAIO de 2010

- 2": At 19, 1-8; SI 67 (68), 2-3, 4-5ac. 6-7ab (R/. 33a) ; Jo 16, 29-33 -34: At 20, 17-27; SI 67 (68), 10-11, 20-21 (R/, 33a); Jo 17, 1-11a - 4": At20, 28-38; SI67 (68), 29-30.33-34.35-36 (R/.33a);Jo 17, 11b$19,5^{\mathrm{a}}:$ At 22, 30; 23, 6-11; SI 15 (16), 1-2a e 5. 7-8. 9-10.11 (R/. 1); Jo 17, 20-26• 6": At 25, 13b-21; SI 102 (103), 1-2. 11-12, 19-20ab (R). 19a); Jo 21, 15-19• Sáb.: At 28, 16-20.30-31; SI 10(11), 4. 5 e 7 (R/. ct. 7b);Jo21, 20-25• SOLENIDADEDEPENTECOSTES: At 2, 1-11; SI 103 (104), 1 ab e 24ac. 29bc-30. 31 e 34 (R/. 30); 1 Cor 12, 3b-7.12-13.

\begin{tabular}{|c|}
\hline 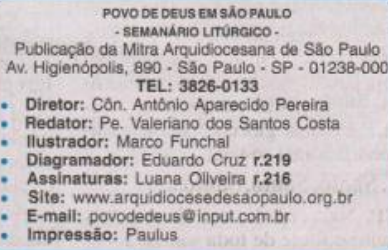 \\
\hline
\end{tabular}




\section{Referências}

BENTO XVI. Compêndio do Catecismo da Igreja Católica. São Paulo: Loyola, 2005.

BLANCO, D. El rito de la Misa como práctica significante. Topicos del Seminário, n. 20, Puebla/ México, p. 43-70, 2008.

BORTOLINI, J. A Missa explicada parte por parte. São Paulo: Paulus, 2006. FIORIN, J. L. As astúcias da enunciação. São Paulo: Ática, 2002.

FONTANILLE, J. Práticas semióticas: imanência e pertinência, eficiência e otimização. In: DINIZ, M. L. V. P.; PORTELLA, J. C. (Orgs). Semiótica e mídia: textos, práticas e estratégias. Bauru: UNESP/FAAC, 2008.

FONTANILLE, J.; ZILBERBERG, C. Tensão e significação. São Paulo: Humanitas, 2001.

JOÃO PAULO II, Papa. Catecismo da Igreja Católica: edição típica vaticana. São Paulo: Loyola, 2000.

LANDOWSKI, E. Passions sans nom. Paris: Presses Universitaires France, 2004.

MAINGUENEAU, D. A Gênese dos discursos. Tradução Sírio Possenti. Curitiba: Criar Edições, 2005. (Original francês).

PANNENBERG, W. Teologia sistemática. v. 1. São Paulo: Paulus, 2009.

RABAÇA, C. A.; BARBOSA, G. G. Dicionário de Comunicação. São Paulo: Ática, 1987.

TATIT, L. Análise semiótica através das letras. São Paulo: Ateliê Editorial, 2001.

ZILBERBERG, C. As condições semióticas da mestiçagem. In: CAÑIZAL, E. P.; CAETANO, K. E. (Orgs.) O olhar à deriva: mídia, significação e cultura. São Paulo: Annablume, 2004. p. 69-101. 
ZILBERBERG, C. Elements de grammaire tensive. Limoges: Pulim, 2006.

ZILBERBERG, C. Louvando o acontecimento. Revista Galáxia, São Paulo, n. 13, p. 13-28, jun. 2007.

Recebido em abril de 2013 Aprovado em agosto de 2013 